\title{
Social care for the migrant population in Spain: needs and strengths of organisations during the COVID-19 pandemic and infodemic
}

\author{
Tamara Bueno Doral, María Lara and Noelia García-Castillo
}

\author{
Tamara Bueno Doral, \\ María Lara and Noelia \\ García-Castillo are all based \\ at the Department of \\ Theories and Analysis of \\ Communication, \\ Complutense University of \\ Madrid, Madrid, Spain.
}

Received 20 October 2020 Revised 10 September 2021 Accepted 18 October 2021

(C) Tamara Bueno Doral, María Lara and Noelia García Castillo. Published by Emerald

Publishing Limited. This article is published under the Creative Commons Attribution (CC BY 4.0) licence. Anyone may reproduce, distribute, translate and create derivative works of this article (for both commercial and non-commercial purposes), subject to full attribution to the original publication and authors. The full terms of this licence may be seen at http://creativecommons.org/ licences/by/4.0/legalcode

Acknowledgements and financing: We gratefully acknowledge the interest and efforts of the persons and institutions that have participated in this investigation, financed by the European Union through the Horizon 2020 program for the project "Reshaping Attention and Inclusion Strategies for Distinctively vulnerable people among the forcibly displaced (RAISD)" (grant agreement 822688).

\begin{abstract}
Purpose - In the past months, the authors have experienced an exceptional global situation that especially affects the most vulnerable population. This paper aims to analyse the needs, strengths and good practices of the organisations that have continued to study with the migrant population during the health crisis. The main objective was to determine how the health, social and communication crisis has affected the management of the organisation itself, the communications with its direct beneficiaries, the communications with the rest of society, as well as the perception that organisations specialised in migration have about how media has communicated the information of COVID-19 and migrant population.
\end{abstract}

Design/methodology/approach - The authors have circulated a questionnaire with open questions that covered the four dimensions previously mentioned.

Findings - The results show the analysis of the answers of 11 of the most important national and international organisations in the field of migration and refuge that operate in Spain.

Originality/value - Key issues have emerged related not only to the principal management concerns, internal digital communication, the adaptability of external communication and the major effort required to provide information about migration but also to innovative good practices. That other third sector organisations focussed on migration will be able to apply in the future and in other geographic areas.

Keywords Migration, Social care, Third sector, Refugees, COVID-19, Good practices, Migrant population Paper type Research paper

\section{Introduction}

The COVID-19 health crisis poses an unprecedented challenge in terms of organisational communication. In the third sector, communication with social groups depends largely on physical and personalised contact. People who are in a situation of vulnerability have great difficulty accessing new technologies and, if this were not enough, their livelihood resources, i.e. basic needs, such as housing, food or supplies, are so scarce that any delay in the care they receive can have dramatic consequences for them.

Third sector organisations in Spain are already at the limit of their normal capacity in terms of human resources (Hänninen et al., 2012). They are taking care of more people than their capacity allows, contributing their good will and commitment to social responsibility to supplement the attention that the State itself should pay to a group such as the forcibly displaced, which is protected by international regulations (ONU, 1951).

All these factors present a challenge to Spanish organisations specialising in migration. In this paper, we present a study of paradigmatic cases that can inspire health and social care 
for migrants, as well as crisis communication applied to migration so that, in crisis situations, challenges can be transformed into strengths. As United Nations High Commissioner for Refugees [UNHCR (2020)] states in its High Commissioner's Dialogue 2020 Concept Note, it is essential to address as follows:

[...] how to amplify innovative, promising practices to mitigate the protection, health, and socioeconomic impacts of the pandemic on persons of concern and their host communities, strengthen the current response and prepare for future outbreaks.

\section{Health, organisation and communication crisis}

The spread of COVID-19 throughout the world is causing an unprecedented crisis not only in the health sector but also at all levels, particularly in the social and economic spheres. This pandemic is particularly unique, due to the way it has affected the population of the whole planet. Back in 2018 García-Marzá (2018) already warned that, in this global social context that pays no regard to international frontiers, "common values and standards are necessary". Therefore, there was already a social demand that required considering "environmental and ethical aspects from a collaborative and responsible approach" (García-Castillo et al., 2020).

The current pandemic, both in terms of the number of countries and the density of population affected, exceeds all those that occurred in the twentieth and twenty-first centuries (Costa-Sánchez and López-García, 2020). Figures continue to rise, but at the time of writing - 31 August $2021-4,847,298$ people have been infected so far in Spain, with 84,146 deaths (Zafra et al., 2021).

In this context, communication is complex and requires the management of variables, such as "timely and correct information, empathy, hope, public trust in the authorities, and effective policies" (Costa-Sánchez and López-García, 2020). In fact, these key aspects are very similar to those identified as decisive in the success of crisis communication in South Korea during the pandemic (Paek and Hove, 2021).

As early as 2004, the World Health Organization (2004) (WHO) pointed out that in terms of health, crisis and communication are closely linked and that "all health crises are also communication crises". The same organisation has registered an unprecedented increase in the number of outbreaks of new infectious diseases, and the lessons learned from their management have confirmed the critical importance of effective communication (Qiu et al., 2016). In addition, Crespo and Garrido (2020) remind us that as follows:

It is important to consider not only what is going to be communicated but how it is going to be communicated, and for this it is necessary to point out the role of government spokespersons, press conferences, committees of experts, as well as the measures taken by the Government and opposition.

Correct transmission of information is vital for citizens to understand the gravity of the situation and agree to cooperate with the measures imposed by the authorities. Good risk communication skills help people formulate a correct perception of that risk, increase their willingness to collaborate and facilitate the integration of all agents in the diagnosis (Qiu et al., 2016). The same authors add that governments stand to lose public trust if they issue contradictory information or if they are perceived to conceal information; aside from the fact that trust needs to be built up over time. For these reasons, the authors consider trust to be the basis of communication, since "maintaining an open and honest attitude and actively engaging stakeholders to address their risk information needs will [...] facilitate multi-sector collaborations in dealing with a public health crisis" (Qiu et al., 2018).

The Spanish survey of 500 participants conducted by Moreno et al. (2020) revealed that trust in public authorities has declined as the crisis has evolved. A paradox revealed by 
Moreno et al. is that "even when the information from the authorities was given in a timely and correct manner, over-information and counter-information rendered some citizens unable to distinguish questionable messages" (2020). The fact is that in times of social alarm, the public looks for "updated, immediate and accurate" information (Seeger et al., 1998); however, an excess of information can be counterproductive, as various studies have shown that repeated media exposure to reports on crises can lead to increased anxiety among readers (Garfin et al., 2020).

Various experts have produced specific recommendations for crisis management and communication during the pandemic. In addition to what has been previously mentioned, Kim and Kreps (2020) have added actively seeking new risks, developing strong relationships with international counterparts and influential social groups, centralising information management, establishing information dissemination strategies, creating direct communication channels and "protecting minority groups who are discriminated against". However, despite the existing academic literature, the theory is not always put into practice. This may be due to a number of reasons, such as belonging to hierarchical organisations or the paternalistic approaches of some leaders (Gesser-Edelsburg, 2021).

The WHO also warned that the "infodemic" (World Health Organization, 2020) makes it difficult for people to locate trusted sources and distinguish between what is true and what is not. The infodemic also amplifies "misinformation with misconstrued statistics, conspiracy theories, rumours, and propaganda" (Stephens, 2020). False data masquerading as scientific facts can spread rapidly through social networks, as consumers are unable to compare them (Lytvynenko, in Sánchez-Duarte and Magallón, 2020). Furthermore, "science and journalism continue to work at different rates, and this determines whether healthcare professionals and citizens are given adequate information" (Rosich et al., 2007, in LópezRico et al., 2020). The sheer volume of news stories has created a situation of saturation and uncertainty about the reliability of the reports (Laato et al., 2020).

Despite this, the role of the media in times of health crisis is more important than ever because "they are in charge of transmitting official messages and informing citizens of preventive measures, and also of reporting events with objectivity following journalistic criteria" (Covello, 2003, in Masip et al., 2020). However, the arrival of the internet brought about a substantial change in the way people access information, which went from being dominated by traditional media to being a combination of audio-visual or text messages on various digital platforms (Moguillansky et al., 2016).

In the survey conducted by Moreno et al. (2020) $86.2 \%$ of respondents got their news from the television, $77.6 \%$ from WhatsApp, $75 \%$ from online newspapers and $42.6 \%$ from the radio. Magazines $(7.4 \%)$, Telegram $(5.7 \%)$ and blogs or websites specialised in alternative therapies (4.6\%) were used to a lesser extent. According to the study by López-Rico et al. (2020), respondents with a lower level of education placed greater trust in television while the more highly educated place more trust in the radio and the press. Social networks, however, are transversal in this regard. In their analysis, Masip et al. (2020) concluded that the general public maintained a critical attitude towards the media, as they considered that they were dominated by their editorial line, sensationalised the news and generated social alarm.

Social care organisations specialising in the migrant population have also had to tackle the infodemic by compiling and disseminating accurate health care and essential information (Nisanci et al., 2020). According to the Norwegian Refugee Council (2020), the stigmatisation and discrimination against refugees and migrants for spreading COVID-19 have severe consequences, not only for migrants and public opinion but also for public health outcomes because migrants and refugees may fear to seek medical care or to reveal their symptoms. In the case of Spain, as analysed by Sánchez-Duarte and Magallón (2020), misinformation through social networks has increased during the pandemic $(36.1 \%)$ while 
the number of hoaxes spread on WhatsApp increased by the same percentage. Subject matter ranged from infection sources to safety, but there was an alarming $28.9 \%$ of false news about migrants.

The infodemic and the spread of fake news during the pandemic have reinforced populism around the globe and reduced support for non-governmental organisations (NGOs) that work with the migrant population. International migration has increasingly become a political tool as some leaders try to divide communities over the issue (IOM, 2020). Back in February 2020, a journalist already warned of the growing xenophobia in Spain against the population of Asian origin (Ontoria, 2020). During summer 2020, the focus shifted towards the "poor housing conditions for many irregular seasonal foreign workers" (El Mundo, 2020). Although the pandemic has demonstrated the positive contribution of the migrant population in Spain, xenophobic attitudes have increased. During the regional election campaign in Madrid in May 2021, VOX, a Spanish right-wing populist party, fuelled the social construction of immigration as a problem with an explicit anti-Muslim discourse that characterises its propaganda (Fernández-Suárez, 2021).

The COVID-19 crisis, apart from generating a multitude of particular crises and leading to an alarming economic and social situation, has brought about an important change in working habits, with the proliferation of teleworking and the intensive use of information technologies for communications. Xifra (2020) adds that it is still too early to evaluate the effectiveness of these new approaches, but everything seems to indicate that they will alter the traditional working habits of all population. These changes might also affect migration services providers or voluntary organisations. However, the most vulnerable groups will be those that may suffer more because of the new challenges in the job market. For instance, Falkenhain et al. (2020) examined how the COVID-19 crisis was affecting forced migrants in Germany and conclude that as follows:

The crisis-induced disruptions led to uncertainties that produced peculiar effects for refugees specifically because they are refugees on their way to become accepted as persons, to become valued in their social roles, to establish themselves as autonomous participants on the labour market, and finally to become recognised as citizens with a secure and permanent residential status.

COVID-19 poses major global challenges for social work that will also affect the future of the discipline. Some of the changes and lessons learnt affecting social care organisations in various countries during the pandemic have been analysed in the burgeoning literature. Among the challenges that have been highlighted are a reduction in staff due to health measures, dwindling economic resources, the greater use of technologies and social workers' fears of being exposed to COVID-19 (Alston et al., 2021). Social workers around the world have experienced an "emotional roller coaster", with feelings of hope, happiness, excitement, fear, sadness, anxiety and frustration, and difficulties resulting from a blurring of boundaries between work and home (Alston et al., 2021; Forsberg, 2021). As with many other workers, they have reported working "in the middle of the unknown" (Nisanci et al., 2020), with a lack of clear procedural guidelines or personal protection equipment in the initial months (Forsberg, 2021; Watterson, 2020). The use of technologies is considered a double-edged sword because the exclusive use of phone calls as a means to contact vulnerable users has entailed a significant loss of non-verbal communication and a reduction in the capacity to identify problems (Forsberg, 2021; Nisanci et al., 2020). Furthermore, forced migrants experience a greater digital divide (Alam and Imran, 2015; Nisanci et al., 2020). The workload of social care organisations has increased their users' needs grow, related to health issues, isolation, financial concerns, domestic violence and homelessness (Alston et al., 2021; Nisanci et al., 2020). Alston et al. (2021) have also focussed on the lack of media coverage concerning the essential work carried out by social workers during the pandemic. Despite the previously mentioned disadvantages, some studies have also reported positive aspects of teleworking in social care, such as reduced travel time, digitalisation and working from home as a "more effective and peaceful" experience (Forsberg, 2021), in addition to opportunities for digital 
health care and for providing information, guidance and protection (Thomas et al., 2021). Moreover, the pandemic has evidenced the potential of civil society organisations (CSOs) for flexibility and adaptability (Nair et al., 2021).

Some authors have concluded their analyses with a series of final recommendations. These include developing contingency plans, creating community-based volunteer networks (Kwan et al., 2021), improving support to home care workers (Dawson et al., 2020), supporting the work of CSOs (Nair et al., 2021), improving remote health care delivery in developing areas (Baiyewu et al., 2020), classifying all social workers as essential and improving digital skills among direct beneficiaries (Molnar et al., 2021).

Some of the literature discusses organisations specialising in the migrant population. In relation to the direct coordination of diverse organisations, UNHCR has established global regular virtual consultations with NGO partners to share good practices and exchange priorities (UNHCR, 2021). Similarly, a group of Spanish academics have created three online seminars related to digital social work, good practices during the lockdown and future challenges (López Peláez et al., 2020). This kind of initiative promotes a network for learning and improvement that directly benefits organisations, workers and final users.

The pandemic has significantly affected highly vulnerable national groups in Spain, with overcrowded housing and sanitary deficiencies rendering social distancing difficult. However, the situation is even worse for migrants, who generally have a weaker social network and less knowledge about access to public services. Moreover, Spanish organisations that collaborate with migrant people fear a sharp decrease in their resources due to a new economic crisis. According to a report presented by the Spanish trade union Workers' Commissions (Comisiones Obreras de Aragón, 2021), the COVID-19 crisis is especially harsh on the most vulnerable groups such as immigrant workers, whose unemployment rate was more than double that of Spanish workers in December 2020. According to Castro (2020), data on infections and deaths disaggregated by nationality have not yet been published in Spain, although data begin to indicate that the trend will be similar to the ones observed in other countries, such as the USA (Gross et al., 2020) or the UK (Public Health England, 2020). Some causes that could explain this trend have been studied by different authors, such as overcrowded living conditions (Kluge et al., 2020) and the over-representation of migrants and refugees among the homeless population in most European countries (Foundation Abbé Pierre-Feantsa, 2015).

States of emergency and lockdowns have exacerbated the previous difficulties experienced by migrants and refugees because of "administrative, financial, legal, and language barriers to access the health system" (World Health Organization, 2018). Due to that, diverse experts and organisations are claiming for "an inclusive approach to refugee and migrant health that leaves no one behind during the COVID-19 pandemic" and that ensures that new actions "do not prevent people from accessing safety, health-care services, and information" (Kluge et al., 2020).

\section{Objectives and methodology}

The main objective of this study has been to determine how the current situation has affected crisis management in the organisation itself, the communications with its direct beneficiaries, the communications with the rest of society, as well as to gauge the opinion of organisations specialising in migration on the media, in terms of how they have communicated information regarding COVID-19 and the migrant population.

For the purposes of the study, we designed a questionnaire with eight questions that covered four dimensions: crisis management in the organisation itself and internal communication management, communication management with the organisation's 
vulnerable groups, external communication management and opinion on information on COVID-19 and the migrant population. We obtained responses from 11 organisations specialised in migrant welfare. We were interested in obtaining a large, varied sample, so we targeted small, large, local, national (Spanish) and international organisations.

In Spain, total lockdown began in March 2020 and the state of alarm was extended to the end of June. Afterwards, a series of urgent prevention measures were adopted at regional level, many of them affecting freedom of movement. Currently, as a measure common to the entire national territory, the use of masks and social distancing have been maintained while vaccination progresses satisfactorily. The responses to the questionnaires were collected in July 2020, referring to the initial months of lockdown.

Organisations and companies in the third sector, albeit to a lesser extent than in the business sector, also compete in terms of resources, designing communication plans and strategies. Therefore, we analysed the results in general terms and thus avoided naming each organisation, although we provide information on its size and scope of action when this will help clarify our results. We mention the name of the organisation whenever their responses do not compromise their competitiveness.

We analysed the results of the questionnaire using qualitative content analysis. The following is a list of the organisations participating in the study, accompanied by a brief description of their activity and the position of the person who responded to the questionnaire (Table 1).

Table 1 Respondent organisations

\begin{tabular}{|c|c|c|}
\hline Organisation & Brief description & Position \\
\hline AMED & $\begin{array}{l}\text { Social and labour market inclusion of populations at } \\
\text { risk or in a situation of social exclusion }\end{array}$ & Project Coordinator \\
\hline Red Acoge & $\begin{array}{l}\text { Federation of } 20 \text { organisations focussed on the welfare } \\
\text { of migrants, refugees and stateless persons }\end{array}$ & Head of Communication \\
\hline Fundación Recover & $\begin{array}{l}\text { Health-care management and development of non- } \\
\text { profit hospitals in Africa, as well as the evacuation and } \\
\text { treatment of African patients in Spain }\end{array}$ & Communication and Marketing \\
\hline $\begin{array}{l}\text { Mundo en } \\
\text { Movimiento }\end{array}$ & $\begin{array}{l}\text { Non-profit organisation focussed on the phenomenon } \\
\text { of migration from a transversal perspective of gender, } \\
\text { migration and human rights }\end{array}$ & Coordinator \\
\hline Kif Kif & $\begin{array}{l}\text { Association of LGTBI + migrants and refugees in } \\
\text { Spain }\end{array}$ & Communication \\
\hline $\begin{array}{l}\text { Fundación La } \\
\text { Merced } \\
\text { Migraciones }\end{array}$ & $\begin{array}{l}\text { Protection and promotion of the inclusion of migrants } \\
\text { and refugees in a situation of vulnerability, particularly } \\
\text { unaccompanied young adult migrants in Spain }\end{array}$ & Communications and Fundraising Manager \\
\hline $\begin{array}{l}\text { Bienvenidxs } \\
\text { Refugiadxs Alcalá } \\
\text { de Henares }\end{array}$ & $\begin{array}{l}\text { Citizen platform of solidarity with refugees that } \\
\text { channels local initiatives that arise spontaneously and } \\
\text { individually }\end{array}$ & Chair \\
\hline Asociación Trabe & $\begin{array}{l}\text { Association specialised in the defence of women's } \\
\text { rights, paying particular attention to violence against } \\
\text { women and to trafficking and sexual exploitation }\end{array}$ & Head of communications \\
\hline CEAR Madrid & $\begin{array}{l}\text { Defence and promotion of Human Rights and the } \\
\text { integral development of refugees, stateless persons } \\
\text { and migrants in need of international protection and/or } \\
\text { at risk of social exclusion }\end{array}$ & Head of Advocacy and Social Participation \\
\hline La Rueca & $\begin{array}{l}\text { Management body of the Municipal Office of } \\
\text { Immigration, Orientation and Social Accompaniment } \\
\text { for the integration of the migrant population of Madrid }\end{array}$ & Administration and Communication Manager \\
\hline UNHCR Spain & $\begin{array}{l}\text { Office of the United Nations High Commissioner for } \\
\text { Refugees in Spain }\end{array}$ & $\begin{array}{l}\text { Senior Protection Associate, in collaboration } \\
\text { with Public Information }\end{array}$ \\
\hline
\end{tabular}




\section{Results \\ Main concerns during adaptation to lockdown: ensuring contact with vulnerable migrants and access to resources}

Organisations have gradually been able to resume face-to-face care by adopting even more stringent occupational health and safety measures and protocols. In this context, what most concerned organisations was the serious social and economic consequences on migrant populations as follows:

The serious social and economic consequences that have had a particular impact on migrant populations are the most worrying reality right now.

Lockdown has made it even more difficult for organisations to act because of the digital divide affecting end users examined earlier (Alam and Imran, 2015; Nisanci et al., 2020). Respondent organisations have worked hard to guarantee accurate information as follows:

The greatest added difficulties have been to access our target population [...] including people with specific needs or at risk, guaranteeing their access to full and complete information adapted to their profiles, problems and risks.

On the other hand, as mentioned by Alston et al. (2021) and Nisanci et al. (2020), there has been a greater demand for basic needs among the migrant population, such as shelter and food, and this has increased the teams' workload. The burden has also been psychological, similar to the emotional roller coaster described by Forsberg (2021) since:

Many actions must be carried out in person, and this is not possible at the current time.

To this must be added the implementation of temporary measures that further facilitate the work-life balance. Other operational concerns have also affected the future of the organisations' activities and the care of end beneficiaries:

[...] ]uncertainty about the grants that fund our activities. The funding calendar has been frozen and we have not received information about the deadlines that will be established.

\section{Teleworking as a good experience for non-governmental organisations' internal communication despite the digital divide}

Seven of the 11 participating organisations stated that their internal communications had not been negatively affected by teleworking, particularly as the weeks went by, as they had already established the appropriate channels before the pandemic.

Nevertheless, some organisations mention different challenges:

The lack of technical means and training (new platforms and digital divide) of staff and users may have influenced our work and led to slower adaptation to the current situation.

We have had to devote a lot of time and effort to reorganising the work of the teams [... . All of this has been accompanied by a series of measures for workplace safety that are more stringent than usual.

We have had to update staff computers and learn how to use new communication platforms without face-to-face problem-solving or tuition. Problems in balancing work and family life make it difficult to hold meetings via video calls.

The main difficulty is still finding the most appropriate channel to execute and articulate internal communication, as well as managing the content, regularity and so on of that communication. 


\section{Innovations introduced in internal communication: technology at centre stage}

Three of the organisations had not introduced any improvements in internal communication. Obviously, organisations that already had such communication channels in place before lockdown were able to adapt faster to the new situation:

Before lockdown began, before being motivated by this situation, Microsoft Teams was implemented, which has notably facilitated internal communication.

Organisations have made use of various communication tools (such as Microsoft Teams, Zoom, Google Meet, WhatsApp, Hangouts, Slack, Telegram or JitsiMeet) to implement new forms of communication, such as internal online training to facilitate greater employee participation or reflection sessions with representatives from different departments or delegations. In general terms, the situation has forced people who were more reluctant to learn new technologies to update their skills. This, in addition to reducing the digital divide among workers, provides yet another approach to internal communication that had been largely neglected till now:

The people most reluctant to adopt new technologies have been forced to learn how to use

them, and this new form of communication is one more alternative that we hardly used before.

Technology and creativity have been at centre stage these past few months.

Video calls were sometime placed spontaneously within teams and were not only always used for the purpose of discussing work but also allowed workers to share personal news and the negative psychological affect that teleworking has on them, their job and their families. Finally, the use of document sharing formats and cloud storage systems has significantly reduced the use of paper and improved the organisation's environmental impact.

\section{Innovative good practices with direct beneficiaries}

Although two entities mention that they have not implemented any positive innovations, the rest provide examples of how such digital creativity arose in times of need.

Above all, the circumstances have compelled the beneficiaries of Asociación Madrid Empleo y Desarrollo (AMED), Red Acoge, Kif Kif or the Trabe Association, for example, to improve their digital skills by making WhatsApp video calls ("something they normally rejected") and processing tasks online. Increasing communications through social networks has made their target groups feel more in touch with the organisations while their papers were being processed. Likewise, because of this previous adaptation, these groups have been able to attend online training and awareness workshops held by organisations such as La Rueca using different tools such as Google Classroom.

Fundación Recover has increased the activities on its telemedicine platform shared by Spanish volunteer doctors and African health professionals. This has allowed a transfer of knowledge and learning as the virus advanced in Spain.

To address the digital divide among its users, AMED developed various tutorials and shared them with other organisations to increase networking.

Comisión Española de Ayuda al Refugiado (CEAR) has launched online initiatives to provide psychological and social support (video tutorials, online leisure proposals, craftwork materials [...]) and to obtain devices to facilitate home schooling for children. They highlight a good practice:

There is one initiative worth highlighting: the launch of RadioCEARMadrid, through the project ConViviendo and with the collaboration of the community radio Onda Merlín. This is a radio programme where refugees can take part from their homes. 
La Merced Migraciones mentions two other communication actions in which its beneficiaries have directly shared their situations with other users:

"Vulnerable people have participated in two projects in which they have been able to share their experiences of lockdown (feelings, hopes, fears [...]. Voces desde el Confinamiento [Voices from Lockdown] (https://youtu.be/ADluMML93HA) and Diarios para el reencuentro [Reunion diaries] (https://youtu.be/KZNNG62Aln4)."

UNHCR Spain has used different resources to access target populations: a survey sent to more than 700 people to find out how they were doing and what difficulties they were facing; the launch of several new telephone lines with an interpreter service; obtaining information through the Refugee Volunteers programme for the purpose of mapping specific needs; the production of informative videos on international protection to be shown in centres; and calls for online meetings with all organisations involved in managing shelters in the International Protection system to learn about the challenges and problems they face in their daily work.

\section{Diverse external communication objectives demonstrating the adaptability of organisations}

The external communication plans of the entities participating in the survey demonstrate their adaptability to uncertainty - as mentioned by Nair et al. (2021) - as the beginning of the Spanish state of alarm as follows:

Lockdown has implied the postponement or adaptation of some projects that were being carried out, for example, in schools.

Some organisations have been inundated with work, while for others lockdown has greatly diminished their activity.

An analysis of the responses given reveals the following objectives and strategies:

- Maintaining contact with users in critical moments they were experiencing.

- Updating the information offered to users, for example, by consolidating the website as an informative reference on care for migrants.

- Making visible the reality of migrants and innovative initiatives that were being carried out at the national and international level in the context of the pandemic.

- Publicising the positive actions and contributions that these people have been making during the pandemic to fight it or help other people through solidarity.

- Supporting different initiatives and campaigns of specific groups, such as domestic workers or the health situation in Sub-Saharan Africa.

- Reinforcing awareness campaigns through social networks.

- Informing and raising awareness about the situation generated by COVID-19 in the city of Madrid, and the measures taken by the administration and public services or by third sector organisations.

- Improving knowledge and experience if other objectives were not possible due to the lockdown.

Due to the lockdown, practically all communication activities have been developed by online means. These include not only the entities' web pages but also newsletters, emails, corporate blogs, social media (Facebook, Instagram, Linkedln, Twitter and YouTube) and platforms, such as Google Meet, Zoom or Jitsi Meet for meetings or online events. Other media are radio podcasts and the local press. 
The forced adaptation of projects and proposals to an online format has meant that beneficiary individuals and families with few technological resources run the risk of being excluded. On the other hand, those activities that required physical presence have been affected in terms of communication and dissemination.

\section{Infodemic: an additional communicative effort}

The organisations have mentioned different aspects that have caused a considerable increase in the workload of the communication departments. The information overload during the lockdown has been an added effort for the entities since it has been necessary to verify the information to avoid the spread of fake news. Added to this was the need to update information, with frequent changes, on care and resources for the migrant population. Great speed was required in the generation of content and some organisations started from a lack of previous experience in this regard as follows:

\footnotetext{
We have tried to verify information so as not to spread hoaxes disseminated by various groups and senders. This has meant an additional effort, as well as having to update the information and monitor frequent news reports.

Sometimes, several campaigns coincided in the same organisation and an additional coordination exercise has been necessary to combine them or prioritise some over others.
}

One organisation states that they have not experienced additional difficulties regarding external communication during the first months of the health crisis. Two entities have even mentioned some opportunities to have a greater impact on their audience as follows:

Although media and society in general are somewhat saturated with information about COVID19 , it is also true that [society] is more receptive and aware of a harsh health reality, which, more than a difficulty, has provided greater opportunities to reach these people.

[... there were many demands to participate in activities, interviews and reports.

\section{Infodemic vs scarce migration information}

Alston et al. (2021) have analysed the lack of media coverage in Australia and New Zealand concerning the essential work of social workers during the pandemic. In our current study, the vast majority of respondents believe that media coverage about migration has been scarce and even biased as follows:

As in other crises, the mass media is based on the urgency of the news, but afterwards there has been no follow-up on the problems.

Media coverage has been low, generally focused on related legislative measures and to a lesser extent on the reality of the consequences of the pandemic on the migrant population.

There was so much media noise that migration has been relegated.

It has only been possible to attract interest from the media and raise awareness in the general public by linking refugees with the impact of COVID, even though this has also been difficult

The collapse of government agencies or the situation of vulnerability due to unemployment or the housing situation are aspects that media have not explored in detail.

UNHCR Spain explains the lack of media coverage of refugees and international protection:

Many journalists who had previously covered immigration/refugees were affected by layoffs, and others have been assigned to cover healthcare and were overwhelmed with work. The 
complexity of not being able to interview people in person - only by phone - due to lockdown has been another challenge for journalists.

Despite the foregoing, one organisation does consider that there has been good media coverage throughout the state of emergency:

I think there has been good media coverage particularly in terms of social resources or immigration formalities: applications for asylum, exams to obtain Spanish nationality, renewals of permits, schooling, social aid, resources for victims of gender violence, soup kitchens, preventive measures, etc. Although most were aimed at the entire population, both indigenous and migrant.

Another organisation states that:

Some media have published stories to raise awareness, while others did so because they saw a news opportunity.

Media scaremongering regarding the prerequisites for receiving the government's Ingreso Mínimo Vital (guaranteed minimum income) generated considerable confusion among the migrant population. Preliminary reports suggested that asylum seekers would also be eligible. This was later refuted, but the conflicting information sparked a "roller coaster of emotions" among the migrant population.

\section{The criminalisation of migration}

A difficulty mentioned by the responding organisations is the xenophobia present in social media.

Organisations criticised situations of criminalisation of migration, including forced migration. The current fear of respondents is the threat of an increase in social polarisation as a result of associating migrants with the emergence of new outbreaks of the disease and even using them as a political tool (as already condemned by Comisión Española de Ayuda al Refugiado, 2020; Fernández-Suárez, 2021; IOM, 2020; Thomas et al., 2021) as follows:

Especially in June, some media outlets have supported the criminalisation of migrants and social polarisation.

Migrants are very frequently associated with social, economic and labour conflicts, etc., without specifying that they are not due to origin but rather to vulnerability.

We are worried that some media and political parties are stigmatising migrants.

This is being used by political and xenophobic groups to stigmatise migrants by branding them as disease carriers.

\section{Conclusions}

The organisations that have participated in our study have had to face numerous difficulties due to the health and social crisis produced by COVID-19. Many of them resemble those experienced by other organisations working with migrants in other countries, such as a heavy increase in workload as the needs of vulnerable beneficiaries increase, forced adaptation to digital social work while experiencing an emotional roller coaster, social polarisation and criminalisation of migration by some media outlets and political parties.

As a result of a qualitative analysis of the responses of 11 of the most important national and international organisations in the field of migration that operate in Spain, other key issues have emerged in the present study, including the principal management concerns, advances in internal digital communication in NGOs, innovative good practices with end 
beneficiaries, the adaptability of external communication and the additional effort required to provide information about migration in the midst of the infodemic.

In terms of internal communication, seven of the 11 organisations believe that far from worsening it has been substantially improved because of the introduction of numerous innovations. In short, the digital divide among workers has been reduced, more internal communication options have been developed and workplace collaboration tools have been more widely accepted by teams.

Regarding external communication, nine of the 11 organisations state that they have also developed very positive innovations as follows: greater digital creativity; improvement in users' digital skills; increased use of various social media for maintaining contact with users; and a significant increase in online training activities aimed at vulnerable groups are some examples of the good practices detected in this research.

All the aspects that have been mentioned in this paper are valuable experiences that migration services providers or voluntary organisations around the world may consider during health, social and communication crisis, such as the current pandemic and infodemic.

\section{References}

Alam, K. and Imran, S. (2015), "The digital divide and social inclusion among refugee migrants: a case in regional Australia", Information Technology \& People, Vol. 28 No. 2, pp. 344-365, doi: 10.1108/ITP-04-2014-0083.

Alston, M., Irons, K., Adamson, C., Boddy, J., Fronek, P., Briggs, L., Hay, K., Howard, A., Rowlands, A., Hazeleger, T. and Foote, W. (2021), "Australian and New Zealand social workers adjusting to the COVID19 pandemic", The British Journal of Social Work, doi: 10.1093/bjsw/bcab163.

Baiyewu, O., Elugbadebo, O. and Oshodi, Y. (2020), "Burden of COVID-19 on mental health of older adults in a fragile healthcare system: the case of Nigeria: dealing with inequalities and inadequacies", International Psychogeriatrics, Vol. 32 No. 10, pp. 1181-1185, doi: 10.1017/S1041610220001726.

Castro, A.M. (2020), "Inmigración, desigualdad y Covid-19: una aproximación desde la realidad en españa”, in Baeninger, R., Vedovato, L.R., Nandy, S., von Zuben, C., Magalhães, L.F., Parise, P., Demétrio, N. and Domeniconi, J. (Eds), Migrações Internacionais e a Pandemia da Covid-19, Nepo/ Unicamp, São Paulo, pp. 138-148.

Comisión Española de Ayuda al Refugiado (2020), "Situación de las personas en necesidad de protección internacional ante la COVID-19", available at: www.cear.es/wp-content/uploads/2020/06/ Informe-COVID_web.pdf (accessed 25 August 2021).

Comisiones Obreras de Aragón (2021), "Impacto de la crisis del Covid-19 en la población extranjera de aragón", available at: https://aragon.ccoo.es/db0b0849e680769dc2eaf832af007d97000051.pdf (accessed 25 August 2021).

Costa-Sánchez, C. and López-García, X. (2020), "Communication and coronavirus crisis in Spain. First lessons", El Profesional de la Información, Vol. 29 No. 3, p. e290304, doi: 10.3145/epi.2020.may.04.

Covello, V. (2003), "Best practices in public health risk and crisis communication", Journal of Health Communication, Vol. 8 No. sup1, pp. 5-8, doi: 10.1080/713851971.

Crespo, I. and Garrido, A. (2020), "The coronavirus pandemic: crisis communication strategies", Más Poder Local, Vol. 41, pp. 12-19.

Dawson, W., Ashcroft, E., Lorenz-Dant, K. and Comas-Herrera, A. (2020), "Mitigating the impact of the COVID-19 outbreak: a review of international measures to support community-based care", available at: https://tccovid.org/2020/05/19/mitigating-the-impact-of-the-covid-19-outbreak-a-review-ofinternational-measures-to-support-community-based-care/ (accessed 24 August 2021).

El Mundo (2020), "Los alojamientos de temporeros extranjeros, un riesgo añadido de coronavirus", 25 July, available at: www.elmundo.es/ciencia-y-salud/salud/2020/07/25/5f1bfOfafc6c83b4228b469b.html (accessed 16 October 2020).

Falkenhain, M., Flick, U., Hirseland, A., Naji, S., Seidelsohn, K. and Verlage, T. (2020), "Setback in labour market integration due to the Covid-19 crisis? An explorative insight on forced migrants' vulnerability in Germany", European Societies, Vol. 23 No. sup1, pp. 1-16, doi: 10.1080/14616696.2020.1828976. 
Fernández-Suárez, B. (2021), "Gender and immigration in VOX: the discourse of the", Migraciones. Publicación Del Instituto Universitario de Estudios Sobre Migraciones, Vol. 51 No. 51, pp. 241-268, doi: 10.14422/mig.i51y2021.009.

Forsberg, V. (2021), "Losing the silver lining-Swedish social workers' experiences of the COVID-19 pandemic", available at: http://hdl.handle.net/2077/68867 (accessed 24 August 2021).

Foundation Abbé Pierre-Feantsa (2015), "An overview of housing exclusion in Europe", available at: www.feantsa.org/download/fap_eu_gb2861057678142834491.pdf (accessed 13 October 2020).

García-Castillo, N., Bueno-Doral, T. and Hänninen, L. (2020), "Responsible research and innovation (RRI) as a driving force for change in corporate communication: new forms of governance and participatory structures", El Profesional de la Información, Vol. 29 No. 3, p. e290313, doi: 10.3145/epi.2020.may.13.

García-Marzá, D. (2018), "Sociedad civil global: hacia una ética de las instituciones", Filosofia Revista da Faculdade de Letras da Universidade Do Porto, Vol. 34, pp. 31-44.

Garfin, D., Silver, R. and Holman, E. (2020), "The novel coronavirus (Covid-2019) outbreak: amplification of public health consequences by media exposure", Health Psychology, Vol. 39 No. 5, pp. 355-357, doi: $10.1037 /$ hea0000875.

Gesser-Edelsburg, A. (2021), "How to make health and risk communication on social media more 'social' during COVID-19", Risk Management and Healthcare Policy, Vol. 14, pp. 3523-3540, doi: 10.2147/RMHP.S317517.

Gross, C.P., Essien, U.R., Pasha, S., Gross, J.R., Wang, S. and Núñez-Smith, M. (2020), "Racial and ethnic disparities in population level Covid-19 mortality", available at: https://ir.uv.es/eSBDK5L (accessed 16 October 2020).

Hänninen, L., Bueno, T., Cela, J., García-Castillo, N., Parras, A. and Gómez, P. (2012), Mujeres Refugiadas y Medios: Análisis de la Visibilidad Mediática de Las Refugiadas en Periódicos Españoles, Fragua, Madrid, Spain.

International Organization for Migration (IOM) (2020), "World migration report", available at: https:// publications.iom.int/books/world-migration-report-2020 (accessed 25 August 2021).

Kim, D.K.D. and Kreps, G.L. (2020), "An analysis of government communication in the United States during the COVID-19 pandemic: recommendations for effective government health risk communication", World Medical \& Health Policy, Vol. 12 No. 4, doi: 10.1002/wmh3.363.

Kluge, H.H.P., Jakab, Z., Bartovic, J., D'Anna, V. and Severoni, S. (2020), "Refugee and migrant health in the COVID-19 response", The Lancet, Vol. 395 No. 10232, pp. 1237-1239, doi: 10.1016/S0140-6736(20)30791-1.

Kwan, C.K., Ling, H.W.H., Cheung, J.C.S. and Chui, E.W.T. (2021), "Safeguarding health equality for the disadvantaged during the COVID-19 pandemic: lessons learned for the social work profession", Qualitative Social Work, Vol. 20 Nos 1/2, pp. 463-469, doi: 10.1177/1473325020973337.

Laato, S., Najmul, A., Nazrul, M. y and Whelan, E. (2020), "What drives unverified information sharing and cyberchondria during the COVID-19 pandemic?", European Journal of Information Systems, Vol. 29, No. 3, pp. 288-305.

López-Rico, C., González-Esteban, J. and Hernández-Martínez, A. (2020), "Polarization and trust in Spanish media during the COVID-19. Identification of audience profiles", Revista Española de Comunicación en Salud, Vol. 1, pp. 77-89, doi: 10.20318/recs.2020.5439.

López Peláez, A., Marcuello-Servós, C., Castillo de Mesa, J. and Almaguer Kalixto, P. (2020), "The more you know, the less you fear: reflexive social work practices in times of COVID-19", International Social Work, Vol. 63 No. 6, pp. 746-752, doi: 10.1177/0020872820959365.

Masip, P., Aran-Ramspott, S., Ruiz-Caballero, C., Suau, J., Almenar, E. and Puertas-Graell, D. (2020), "News consumption and media coverage during the confinement by Covid-19: information overload, ideological bias and sensationalism", El Profesional de la Información, Vol. 29 No. 3, p. e290312, doi: 10.3145/epi.2020.may.12.

Moguillansky, M., Ollari, M. and Rodríguez, G. (2016), "Nuevos hábitos informativos: reflexiones teóricometodológicas a partir del auto-análisis", IX Jornadas de Sociología de la UNLP, Universidad Nacional de La Plata, Ensenada, pp. 1-14.

Molnar, B.E., Scoglio, A.A. and Beardslee, W.R. (2021), "Community-level prevention of childhood maltreatment: next steps in a world with COVID-19", International Journal on Child Maltreatment: Research, Policy and Practice, Vol. 3 No. 4, pp. 467-481, doi: 10.1007/s42448-020-00064-4. 
Moreno, A., Fuentes-Lara, C. and Navarro, C. (2020), "Covid-19 communication management in Spain: exploring the effect of information-seeking behavior and message reception in public's evaluation", El Profesional de la Información, Vol. 29 No. 4, p. e290402, doi: 10.3145/epi.2020.jul.02.

Nair, P., Vera Espinoza, M., Zapata, G.P., Tiwary, S., Castro, F.R., Nizami, A., Jorgensen, N., Yadav, A., Oza, E., Khan, F., Ranjan, R., Zocchi, B., Barve, S. and Barraco, M. (2021), "Migration, pandemic and responses from the third sector: lessons from Brazil and India", available at: www.qmul.ac.uk/gpi/ projects/migpanbrin/ (accessed 25 August 2021).

Nisanci, A., Kahraman, R., Alcelik, Y. and Kiris, U. (2020), "Working with refugees during COVID-19: social worker voices from Turkey", International Social Work, Vol. 63 No. 5, pp. 685-690, doi: 10.1177/ 0020872820940032.

Norwegian Refugee Council (2020), "10 Things you should know about coronavirus and refugees", available at: www.nrc.no/news/2020/march/10-things-you-should-know-about-coronavirus-and-refugees/ (accessed 15 October 2020).

Ontoria, H. (2020), "Xenofobia y racismo, una epidemia más contagiosa que el coronavirus", Público, 3 February, available at: httpS://BLOGS.PUBLICO.ES/CONMDE/2020/02/03/EPIDEMIA-CORONAVIRUSMUROS/ (accessed 13 October 2020).

ONU (1951), "Convention relating to the status of refugees", United Nations, Treaty Series, Vol. 189, p. 137, available at: www.refworld.org.es/docid/47160e532.html (accessed 13 July 2020).

Paek, H. and Hove, T. (2021), "Information communication technologies (ICTs), crisis communication principles and the COVID-19 response in South Korea", Journal of Creative Communications, Vol. 16 No. 2, pp. 213-221, doi: 10.1177/0973258620981170.

Public Health England (2020), "Disparities in the risk and outcomes of COVID-19", PHE Publications London, available at: https://ir.uv.es/JDH12v8 (accessed 16 October 2020).

Qiu, W., Rutherford, S., Chu, C., Mao, A. and Hou, X. (2016), "Risk communication and public health", Global Journal of Medicine and Public Health, Vol. 5 No. 4, pp. 1-11.

Qiu, W., Chu, C., Hou, X.y., Rutherford, S., Zhu, B., Tong, Z. and Mao, A. (2018), "A comparison of china's risk communication in response to SARS and H7N9 using principles drawn from international practice", Disaster Medicine and Public Health Preparedness, Vol. 12 No. 5, pp. 587-598, doi: 10.1017/dmp.2017.114.

Rosich, L., Morales, P. and Bosch, F. (2007), "Boletín REAP", Vol. 4, No. 3, available at: www.reap.es/ boletin/25_BOLETINREAP2007_JUL_SEP.pdf (accessed 14 July 2020).

Sánchez-Duarte, J. and Magallón, R. (2020), "Infodemia and COVID-19. Evolution and viralization of false information in Spain", Revista Española de Comunicación en Salud, Vol. 1 No. suplemento, pp. 31-41, doi: 10.20318/recs.2020.5417.

Seeger, M., Sellnow, T. and Ulmer, R. (1998), "Communication, organization and crisis", Annals of the International Communication Association, Vol. 21 No. 1, pp. 231-276.

Stephens, M. (2020), "A geospatial infodemic: mapping twitter conspiracy theories of COVID-19", Dialogues in Human Geography, Vol. 10 No. 2, pp. 276-281, doi: 10.1177/2043820620935683.

Thomas, J., de Wit, E.E., Radhakrishnan, R.K., Kulkarni, N. and Bunders-Aelen, J.G. (2021), "Mitigating the COVID-19 pandemic in India: an in-depth exploration of challenges and opportunities for three vulnerable population groups", Equality, Diversity and Inclusion: An International Journal, doi: 10.1108/EDI-09-2020-0264.

UNHCR (2020), "High commissioner's dialogue on protection challenges: protection and resilience during pandemics. Concept note", available at: www.unhcr.org/5ed754284\#_ga= 2.246215948.923313182.1602847469-1188850527.1560860744 (accessed 16 October 2020).

UNHCR (2021), "UNHCR-NGO 2021 monthly consultations", available at: www.unhcr.org/unhcr-ngo2021-monthly-consultations.html (accessed 25 August 2021).

Watterson, A. (2020), "COVID-19 in the UK and occupational health and safety: predictable not inevitable failures by government, and trade union and nongovernmental organization responses", New Solutions: A Journal of Environmental and Occupational Health Policy, Vol. 30 No. 2, pp. 86-94, doi: 10.1177/1048291120929763.

World Health Organization (2004), "Sixth futures forum on crisis communication", available at: www.euro. who.int/document/E85056. pdf (accessed 11 July 2020).

World Health Organization (2018), "Report on the health of refugees and migrants in the WHO European region: no public health without refugee and migrant health", available at: https://apps.who.int/iris/ 
World Health Organization (2020), "Rolling updates on Coronavirus disease (covid-19)", available at: www. who.int/docs/default-source/coronaviruse/situation-reports/20200202-sitrep-13-ncov-v3.pdf (accessed 10 July 2020).

Xifra, J. (2020), "Corporate communication, public relations and reputational risk management in the days of Covid-19", El Profesional de la Información, Vol. 29 No. 2, p. e290220, doi: 10.3145/epi.2020.mar.20.

Zafra, M., Clemente, Y., Blanco, P., Sevillano, L. and Grasso, D. (2021), "Casos confirmados de coronavirus en españa y en el mundo", El País, daily updated, available at: https://elpais.com/sociedad/ 2020/07/27/actualidad/1595838623_808240.html (accessed 31 August 2021).

\section{Further reading}

Henley, L.J., Henley, Z.A., Hay, K., Chhay, Y. and Pheun, S. (2021), "Social work in the time of COVID-19: a case study from the global south", The British Journal of Social Work, Vol. 51 No. 5, pp. 1605-1622, doi: 10.1093/bjsw/bcab100.

Lázaro-Rodríguez, P. and Herrera-Viedma, E. (2020), "News on covid-19 and 2019-nCoV in Spanish media: the role of digital media in times of confinement", El Profesional de la Información, Vol. 29 No. 3, p. e290302, doi: 10.3145/epi.2020.may.02.

Lytvynenko, J. (2020), "Here's a running list of the latest hoaxes spreading about the coronavirus", BuzzFeed News, 24 March, available at: www.buzzfeednews.com/article/janelytvynenko/coronavirusfake-news-disinformation-rumors-hoaxes (accessed 20 July 2020).

Sepúlveda-Hernández, E. (2021), "Feeling and pondering the COVID-19 pandemic through the systematization of an experience in social work", Prospectiva, Vol. 31, pp. 131-150, doi: 10.25100/prts.v0i31.10653.

\section{About the authors}

Tamara Bueno Doral is a lecturer and Researcher at Complutense University since 2008. She holds a PhD in Audiovisual Communication and Advertising, she has also worked as a Filmmaker, Producer and Curator of exhibitions. Specialist in Responsible research and innovation (RRI) and Communication applied to vulnerable groups. He has been an active member in a dozen competitive research projects funded by the Spanish Government and the European Union. She is the author of 24 publications distributed among indexed journals and book chapters published by prestigious publishers.

María Lara has been a lecturer specialised in Audiovisual Communication since 2003 (PhD since 2011). She has published a monograph, several book chapters and several articles in indexed scientific journals. She has participated in several research projects, among them, 2 H2020 projects (RAISD and FoTRRIS), where she has carried out research and dissemination activities with the creation of different audiovisual pieces. She also works as a filmmaker and film editor since 1994. Her professional activity focusses on cinema. She has edited 12 films, among which several of the films made by Fernando Colomo, an internationally recognised Spanish film director. María Lara is the corresponding author and can be contacted at: mlara04@ucm.es

Noelia García-Castillo is a lecturer in the Department of Communication Theories and Analysis of the Complutense University of Madrid, specialised in Communication, RRI and especially vulnerable groups. After nine years of teaching and research experience, she has participated in several research projects, among which are "RAISD" and "FoTRRIS" (H2020 Program) and other initiatives funded by the Ministry of Economy and Competitiveness, the Ministry of Education (FPU Program) and Banco Santander.

For instructions on how to order reprints of this article, please visit our website: www.emeraldgrouppublishing.com/licensing/reprints.htm

Or contact us for further details: permissions@emeraldinsight.com 